\title{
The Study of Impact of Tofu Industrial Waste Treatment Plant on Value of Chemical Oxygen Demand Level in Residents Well of Central Lamper Village, Semarang-Indonesia
}

\author{
Nabila Widya Anugraheni ${ }^{1}$ and Slamet Isworo ${ }^{1 \star}$ \\ ${ }^{1}$ Department of Health, Dian Nuswantoro University, Semarang, Indonesia.
}

Authors' contributions

This work was carried out in collaboration between the both authors. NWA authors designed the study, wrote the protocol, and wrote the first draft of the manuscript. SI and NWA authors managed the research analysis. The SI authors managed a literature search and performed statistical analyses. Both authors read and agreed to the final manuscript.

Article Information

DOI: $10.9734 / A R R B / 2021 /$ v36i830415

Editor(s):

(1) Prof. Tunira Bhadauria, Kanpur University, India. (2) Dr. Manikant Tripathi, Dr. Ram Manohar Lohia Avadh University, India.

Reviewers:

(1) Prayitno, State Polytechnic Of Malang, Indonesia. (2) Jayanudin, Universitas Sultan Ageng Tirtayasa, Indonesia. Complete Peer review History: https://www.sdiarticle4.com/review-history/72591

Case Study

Received 15 June 2021

Accepted 21 August 2021

Published 26 August 2021

\section{ABSTRACT}

Background and Objective: The existence of a tofu waste treatment plant in residential areas and reports from the public about the unpleasant odor in several wells made residents worried about the impact of the intrusion of tofu waste treatment plant waste. This study aims to assess the impact of possible intrusion of waste from tofu waste treatment plants into residents' wells.

Methods: This type of research is descriptive with a survey method. Samples from the research site were analyzed in the laboratory by the titration method based on the value of chemical oxygen demand, compared with Government Regulation of the Republic of Indonesia No. 82 Th. 2001 concerning water quality management and water pollution control.

Results: The results of the measurement of the chemical oxygen demand value of the Bajak river were $51.8 \mathrm{mg} / \mathrm{L}$ (starting point) and $238 \mathrm{mg} / \mathrm{L}$ (end point). The value of chemical oxygen demand in resident wells is as follows: resident well 1 of $12.2 \mathrm{mg} / \mathrm{L}$, resident well 2 of $9.12 \mathrm{mg} / \mathrm{L}$, resident well 3 
of $3.05 \mathrm{mg} / \mathrm{L}$, residential well $4 \mathrm{mg} / \mathrm{L}$ of $33.05 \mathrm{mg} / \mathrm{L}$. L, resident well 5 is $3.05 \mathrm{mg} / \mathrm{L}$, resident well 6 is $15.2 \mathrm{mg} / \mathrm{L}$, resident well 7 is $27.4 \mathrm{mg} / \mathrm{L}$ and resident well 8 is $3.05 \mathrm{mg} / \mathrm{L}$.

Conclusion: The value of chemical oxygen demand in the Bajak river exceeds the quality standard, while the value of chemical oxygen demand in resident wells shows that the farther from the tofu waste treatment plant, the smaller the concentration value of chemical oxygen demand. .

Keywords: Chemical oxygen demand; resident well; wastewater treatment installation; domestic waste; tofu industrial waste.

\section{INTRODUCTION}

The clean water is water that is used by humans and living things to meet the needs of daily life, namely as raw material for drinking water, for bathing, washing and latrine purposes, supporting modes of transportation, agricultural needs, industrial needs, and needs for recreation [1] [2] Sources of clean water in shallow groundwater or wells needed by humans need to pay attention to the quantity of water to maintain the availability of clean water sources and maintain the quality of clean water sources from contaminants such as chemicals, pathogenic bacteria and radioactivity that can affect color, smell, and taste. Therefore, water quality must meet the requirements according to the parameters based on Government Regulation of the Republic of Indonesia Number 32 of 2017 [3].

The existence of industry in residential areas can produce waste that can affect the quality of groundwater used by the community so that the water quality does not qualify as clean water. Waste-producing industries that can pollute the environment and clean water [4] for example, are the tofu- making industry located in the residential area of Lamper Tengah Village, Semarang, Indonesia.

Resident well water can be polluted due to the intrusion of tofu industry waste into resident well water, causing water quality parameters to exceed the quality standard criteria as well as non-optimal waste treatment results can affect water quality, both shallow well water and river water so that the ecological burden becomes not balanced [5]. The initial survey of the tofu-making industrial liquid waste which has undergone processing at the Waste Treatment Plant at the outlet, is cloudy white in color and still smells bad, reduces environmental aesthetics and is worried that it can contaminate well water.

This study aims to study the impact of the tofu waste treatment installation on the quality of well water based on chemical oxygen demand (cod) value.

\section{METHODS}

This type of research is descriptive by using survey method and cross sectional approach [6] The samples studied were resident well water with a total of 8 points of collection and 2 point samples of river water, sampling based on the category of distance from the tofu waste treatment plant, namely close distance. medium and far from the tofu waste treatment installation point.

The titration method used for the determination of chemical oxygen demand (cod) is oxidationreduction titration using a solution of Ferro Ammonium Sulfate (FAS), after testing, the value of chemical oxygen demand (cod) was obtained from the titrimetric method of SNI 6989.73:2019 [7]. Data analysis using the comparative technique is to compare the chemical oxygen demand value of resident well water, chemical oxygen demand value of river water chemical oxygen demand value of tofu processing wastewater in accordance with Government Regulation of the Republic of Indonesia No. 82 Th. 2001 [8]. The sampling in this research was carried out at the following coordinates: (Fig. 1).

\section{RESULTS AND DUSCUSSION}

The tofu industry in the village of Lamper Tengah Semarang is a small industry produced by local residents. This industry has very limited capital with industry managers usually the head of the household or family members, because of its small scale, production activities can be carried out at home, therefore the industry is located in a residential area. The development of the tofu industry in that location has a positive impact on improving the economy of the community, but also has a negative impact on the surrounding environment due to the waste generated. This has brought special attention to the local government of the Semarang by providing an integrated tofu industrial waste processing installation facility. The waste treatment plant 
was built in 2003 under the supervision of the Semarang Environment Service. It is necessary to study the effectiveness of the tahu industrial waste treatment plant in Lamper Tengah, Semarang because the waste treatment plant has been in operation for a long time and there are several sub-districts regarding the quality of wells that have an unpleasant odor, especially wells that are close to the location of the waste treatment plant [9].

The results of the tofu industrial production process produce liquid waste which is channeled through pipes to an integrated waste treatment plant [10]. Conditions along the banks of the
Bajak river are residential areas that produce domestic waste that is dumped directly into drainage channels and rivers, this causes a high burden of pollution on the environment (Fig 2 and Fig 3) Residents who live around riverbanks and locations around the sewage treatment plant still use well water to meet their daily needs, including as a source of drinking water, so it is possible that well water can be polluted by domestic waste and intrusion from tofu waste treatment plants into the water resident wells [11]. Fig. 2 shows the environmental conditions around the banks of the Bajak river and Fig. 3 shows the conditions of the Bajajk river as follows:

Table 1. Coordinates of sampling location

\begin{tabular}{lll}
\hline No & Location & Coordinate \\
\hline 1 & Resident's Well 1 & $110.4418103-7.010133784$ \\
2 & Resident's Well 2 & $110.4420998-7.008776686$ \\
3 & Resident's Well 3 & $110.4420367-7.008624179$ \\
4 & Resident's Well 4 & $110.4418436-7.008551367$ \\
5 & Resident's Well 5 & $110.442042-7.00832741$ \\
6 & Resident's Well 6 & $110.4417674-7.007992034$ \\
7 & Resident's Well 7 & $110.4417343-7.007836285$ \\
8 & Resident's Well 8 & $110.4416503-7.00764543$ \\
9 & Waste treatment plant 1 & $110.4417183-7.009894378$ \\
10 & Waste treatment plant 2 & $110.4417057-7.010098448$ \\
11 & Bajak River 1 & $110.4417183-7.009894378$ \\
12 & Bajak River 2 & $110.4415056-7.007543225$ \\
\hline
\end{tabular}

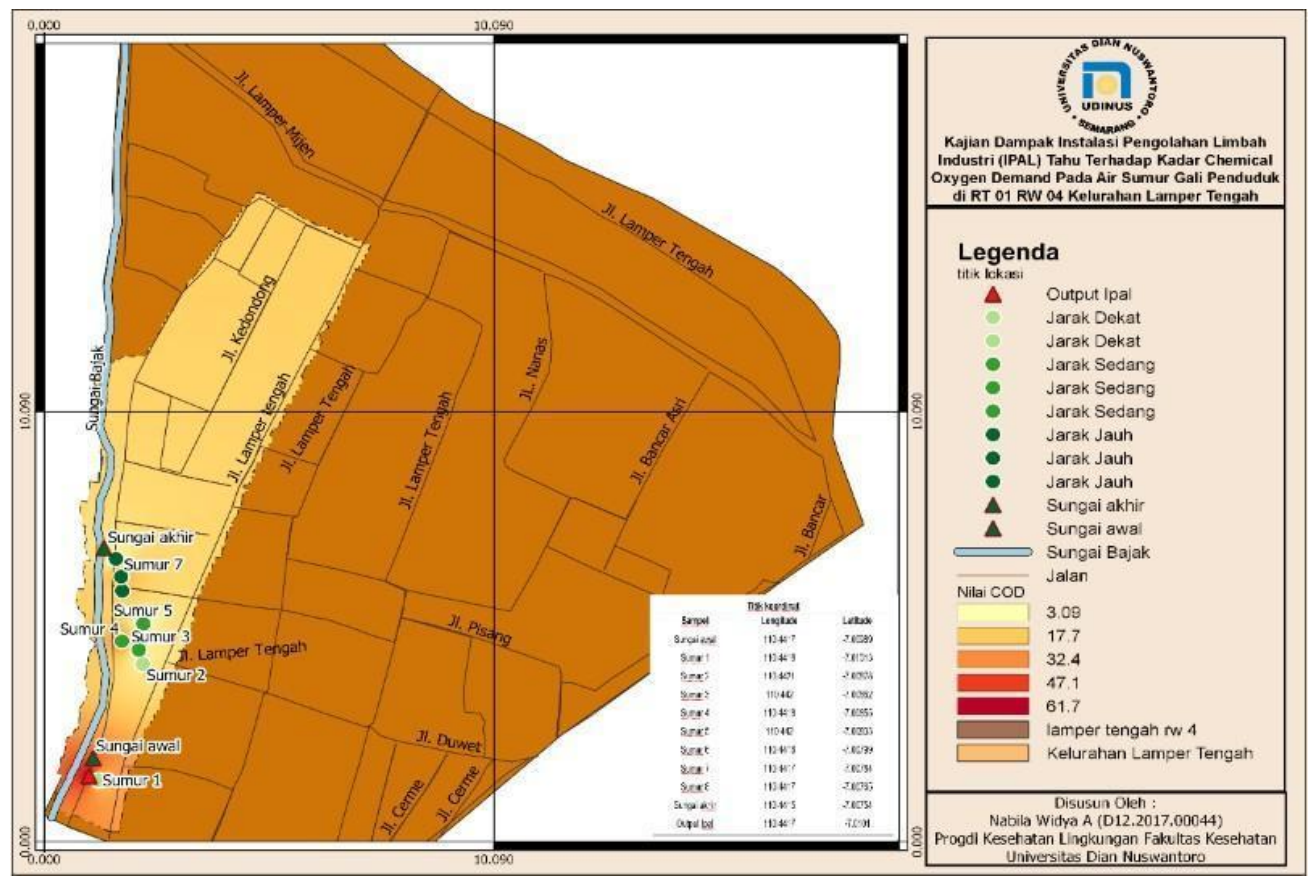

Fig. 1. The Location of Sampling 


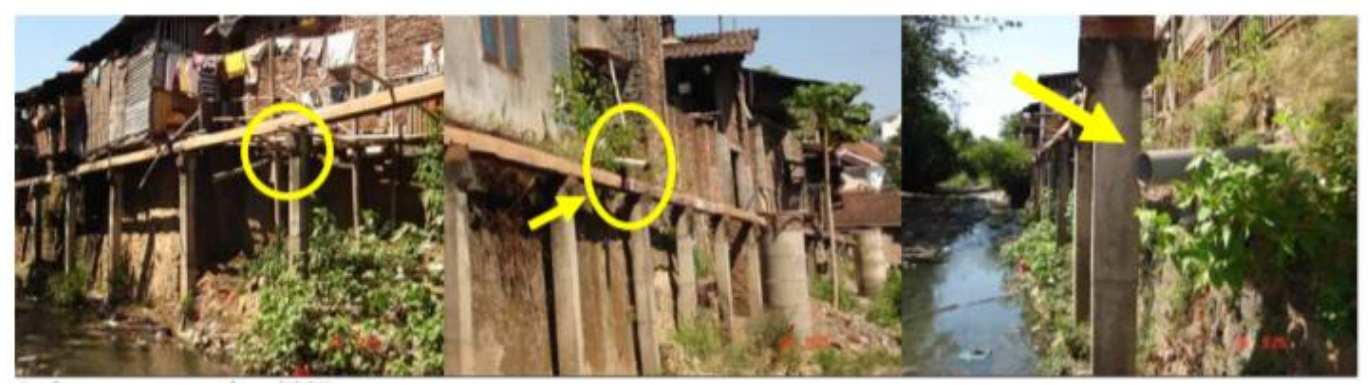

Fig. 2. Disposal of domestic waste at the location of the Bajak river [12]
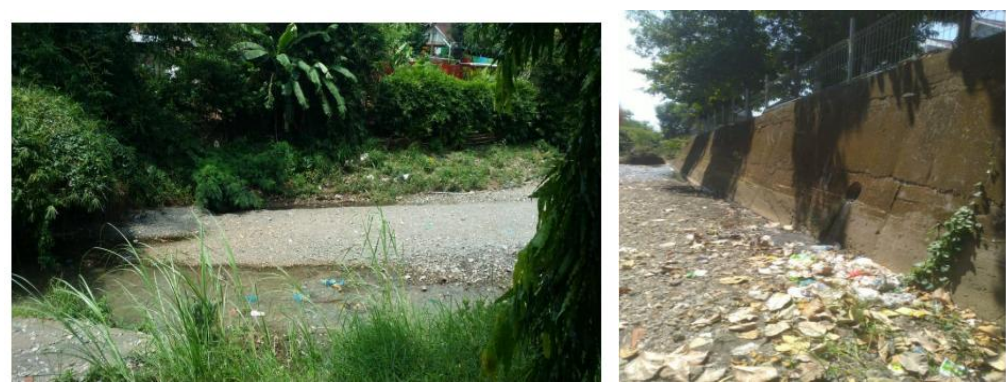

Fig. 3. The condition of the river Bajak

An initial survey conducted on July 29, 2021, some residents living around the tofu industrial waste treatment plant stated that the well water belonging to some residents smelled bad, giving rise to the perception that the well water was contaminated with tofu waste liquid waste. processing plant.

Based on the general description of the research location, a study of the impact of the Tofu industrial waste treatment plant on the value of the level of chemical oxygen needs in the residents' well of Lamper Tengah Village, Semarang-Indonesia was carried out. Table 2 is the measurement results of Chemical oxygen demand at the inlet and outlet of the tofu waste treatment plant, as follows.

Fig. 4 shows the percentage of the ability of tofu waste processing installations in reducing COD concentrations, as follows.

Based on Table 2, the chemical oxygen demand (cod) value can be reduced with an average decrease of $12057 \%$. (The average decrease from $1521.25 \mathrm{mg} / \mathrm{lt}$ to $61.97 \mathrm{mg} / \mathrm{l}$ ) with the average final result that meets the quality standard for waste treatment is an average of $61.97 \mathrm{mg} / \mathrm{lt}$ from the quality standard of $275 \mathrm{ml} / \mathrm{lt}$. The effectiveness of the waste treatment plant performance based on data from January to
October 2021 shows negative results, this shows the effectiveness of the waste water treatment plant from January to October 2021 is getting better (decreasing), with the modeling equation $y$ $=-7,9389 x+45,511$.

Fig. 5. Tofu waste treatment plant in Central Lamper District, Semarang, as follows.

The processing waste from the tofu waste treatment plant is then channeled through a drainage channel to the Bajak river. Table 2 is the data from the measurement of river water quality based on the chemical oxygen demand value at the sampling point before the waste disposal outlet and after disposal in the Bajak river, as follows.

Fig. 6 shows that the predictive value of chemical oxygen demand (cod) before the WWTP result sewer has a model equation value of $y=-$ $0.0036 x+250.54$ this indicates a decreasing trend in the COD value, while the predictive value of chemical oxygen demand (COD) after the WWTP result sewer shows the value of the modeling equation $y=0.1366 x-5885$ is the trend of increasing COD value.

Fig. 7 shows the average value of Chemical Oxygen Demand before the WWTP channel (46.86 $\mathrm{mg} / \mathrm{L})$ and after the WWTP channel $(103.352 \mathrm{mg} / \mathrm{L})$ the Bajak river flows. 
The measurement data shows that the concentration of chemical oxygen demand (cod) in the bajjak river after the waste disposal point from the WWTP has a higher chemical oxygen demand (cod) concentration, this is due to the entry of domestic waste due to the activities of the surrounding community [13]. Fig. 7 shows the comparison of the average concentration of chemical oxygen demand (cod) values before the sampling point and after the sampling point. as follow :

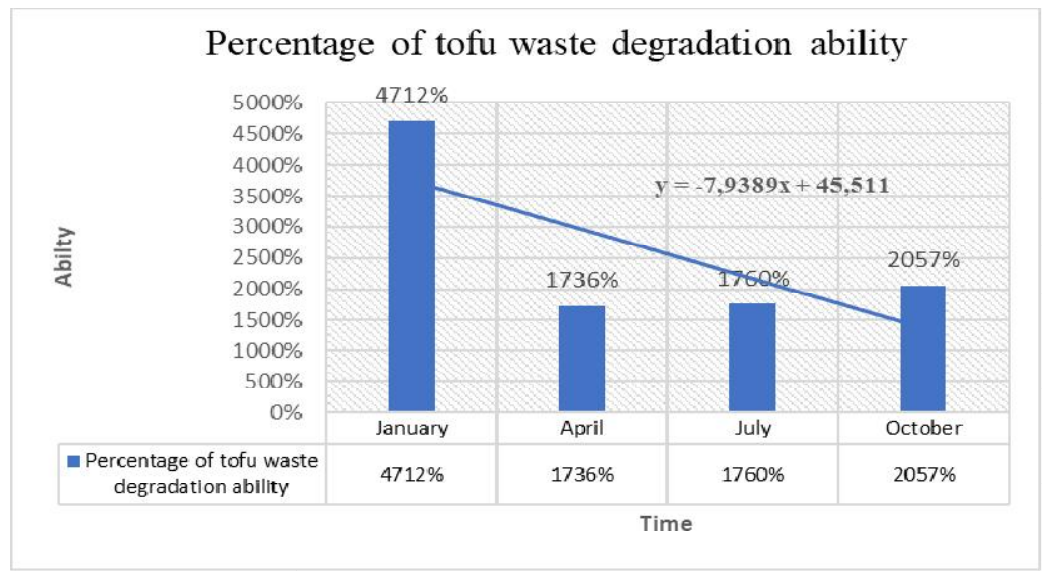

Fig. 4 . Degradation effectiveness of Tofu waste treatment plant (\%)

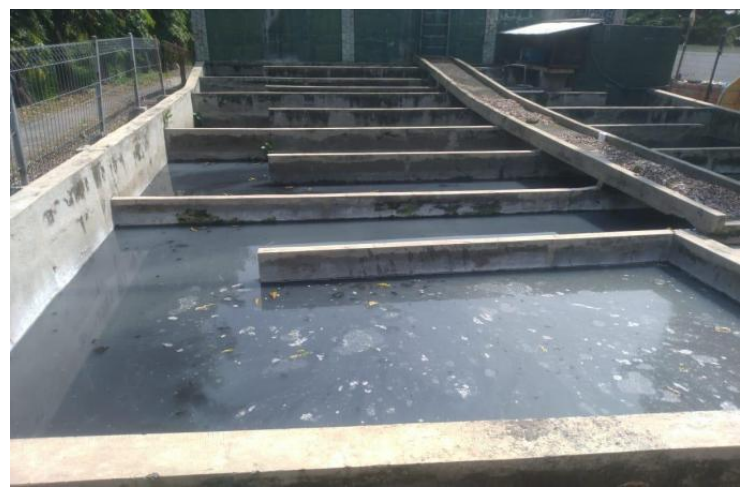

Fig. 5. Tofu Waste Treatment Plant, Central Lamper Village, Semarang-Indonesia

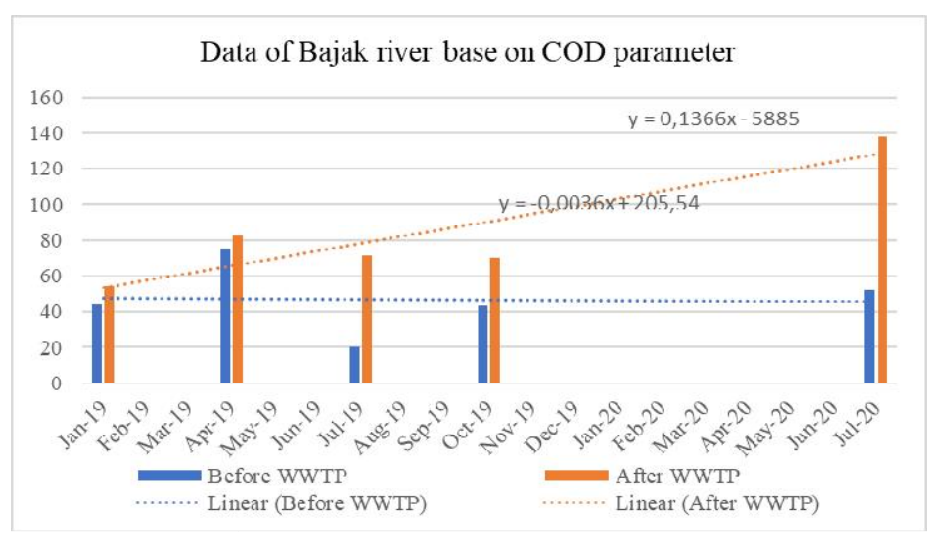

Fig. 6. Data on COD values before and after the point of disposal of WWTP waste in the Bajak river 
Anugraheni and Isworo; ARRB, 36(8): 98-107, 2021; Article no.ARRB.72591

Table 2. The value of wastewater quality inspection at waste treatment plants with chemical oxygen demand (COD) value

\begin{tabular}{|c|c|c|c|c|c|c|c|}
\hline Location & Parameter & $\begin{array}{l}\text { Quality } \\
\text { Standard }\end{array}$ & January & April & July & October & Average \\
\hline Inlet & COD & $275 \mathrm{mg} / \mathrm{L}$ & $2500 \mathrm{mg} / \mathrm{L}$ & $1311 \mathrm{mg} / \mathrm{L}$ & $1071,5 \mathrm{mg} / \mathrm{L}$ & $1202,5 \mathrm{mg} / \mathrm{L}$ & $1521,25 \mathrm{mg} / \mathrm{L}$ \\
\hline Outlet & COD & $275 \mathrm{mg} / \mathrm{L}$ & $53,06 \mathrm{mg} / \mathrm{L}$ & $75,51 \mathrm{mg} / \mathrm{L}$ & $60,87 \mathrm{mg} / \mathrm{L}$ & $58,45 \mathrm{mg} / \mathrm{L}$ & $61,97 \mathrm{mg} / \mathrm{L}$ \\
\hline
\end{tabular}

Table 3. Data of Bajak river water quality inspection based on COD value

\begin{tabular}{|c|c|c|c|c|c|c|c|c|}
\hline Location & Parameter & QS & Jan-19 & Apr-19 & Jul-19 & Oct-19 & Jul-20 & Avg \\
\hline $\begin{array}{l}\text { Sampling before the WWTP result } \\
\text { sewer }\end{array}$ & COD & $25 \mathrm{mg} / \mathrm{L}$ & $44,03 \mathrm{mg} / \mathrm{L}$ & $75,51 \mathrm{mg} / \mathrm{L}$ & $19,97 \mathrm{mg} / \mathrm{L}$ & $43,02 \mathrm{mg} / \mathrm{L}$ & $51,8 \mathrm{mg} / \mathrm{L}$ & $45,63 \mathrm{mg} / \mathrm{L}$ \\
\hline $\begin{array}{l}\text { Sampling after the WWTP result } \\
\text { sewer }\end{array}$ & COD & $25 \mathrm{mg} / \mathrm{L}$ & $54,03 \mathrm{mg} / \mathrm{L}$ & $82,93 \mathrm{mg} / \mathrm{L}$ & $71,78 \mathrm{mg} / \mathrm{L}$ & $70,02 \mathrm{mg} / \mathrm{L}$ & $238 \mathrm{mg} / \mathrm{L}$ & $83,53 \mathrm{mg} / \mathrm{L}$ \\
\hline
\end{tabular}

sewer

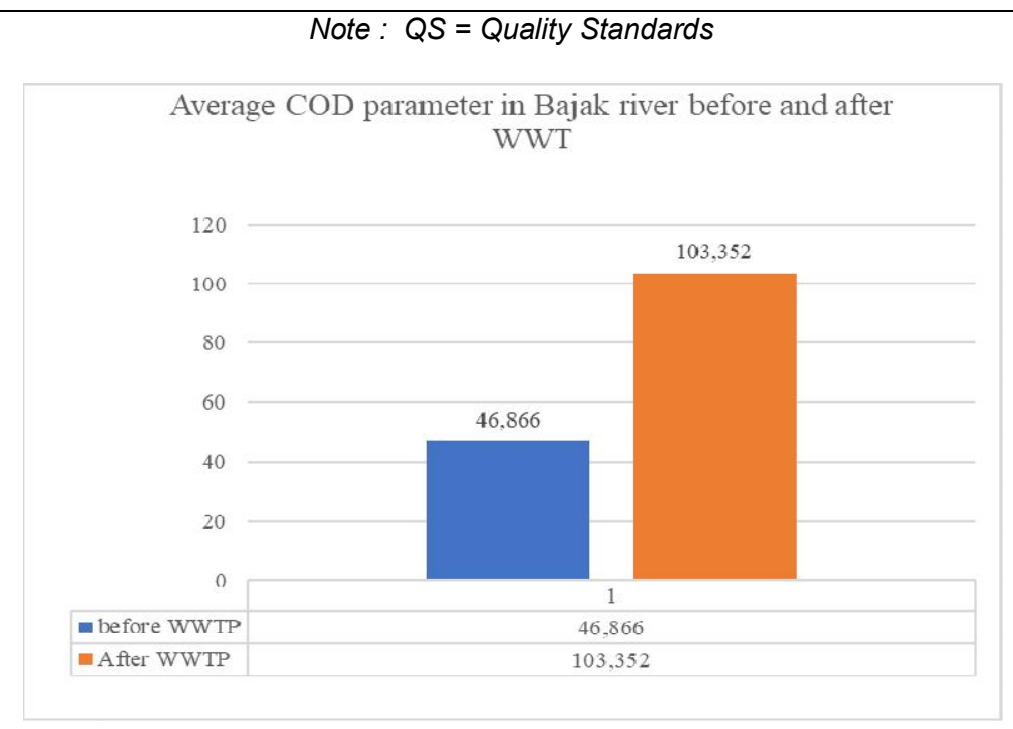

Fig. 7. The Average data of chemical oxygen demand (cod) value inspection results in Bajak river before and after waste water treatment plant 
The modeling results show that the concentration of chemical oxygen demand (COD) after the sewer shows a positive trend with the modeling equation $y=35,530 x+5,157$ (the trend is getting worse based on the increase in the concentration of chemical oxygen demand), whereas before the sewer there is a negative trend with the equation $y=-1,695 x+51,951$ (the trend is getting better/the chemical oxygen demand (cod) concentration is decreasing), but the chemical oxygen demand (cod) measurement results at each sampling point are above the quality standard determined based on the Attachment to the Government Regulation. 82 of 2001, the chemical parameter is the value of chemical oxygen demand with a quality standard of $25 \mathrm{mg} / \mathrm{L}$. The condition of the Bajak river waters based on chemical oxygen demand (cod) value is in the bad category. This condition can lead to intrusion of polluted river water into resident wells. This is a special concern, because there are public complaints about the occurrence of unwanted odors in resident well water [14].

Sanitation is one part of urban water infrastructure that plays an important role. Good and bad sanitation will affect the quality of the environment, which directly or indirectly will have an impact on the quality of ground water and public health [15] The existence of raw water as a source of clean water has an important role in improving the quality of life of people in an area [14]. Raw water that can be used as a source of clean water is surface water, rain water and ground water (shallow well water) [16]. The village of Lamper Tengah is one of the areas where the community still uses groundwater (shallow well water) as raw water for daily needs (bathing. washing and latrines). The sanitation system/disposal system for the residents' household waste is important in maintaining the quality of ground water because an improper waste disposal system will cause contamination of groundwater quality in this case the resident's shallow well water [17].

The results of measurements with chemical oxygen demand (cod) value in resident well water in the village of Lamper Tengah are shown in Table 4, as follows.

The results of observations on the construction of resident wells in the Lamper Tengah sub-district area adjacent to the tofu industrial waste treatment plant, as shown in Fig. 8, are as follows:

Fig. 8 shows the condition of the community wells observed during the study, as follows.

The results of observations based on the construction conditions of residents' wells, 8 resident wells are adjacent to the tofu industrial waste treatment plant, but the ones that are still used by residents are well no. 1, 2, 3, 5 and 8 , while wells no. 4,6 and 7 are not used by residents because they smell bad. In this study, simulations were carried out on wells that are still used by residents. Fig. 9 shows a simulation of
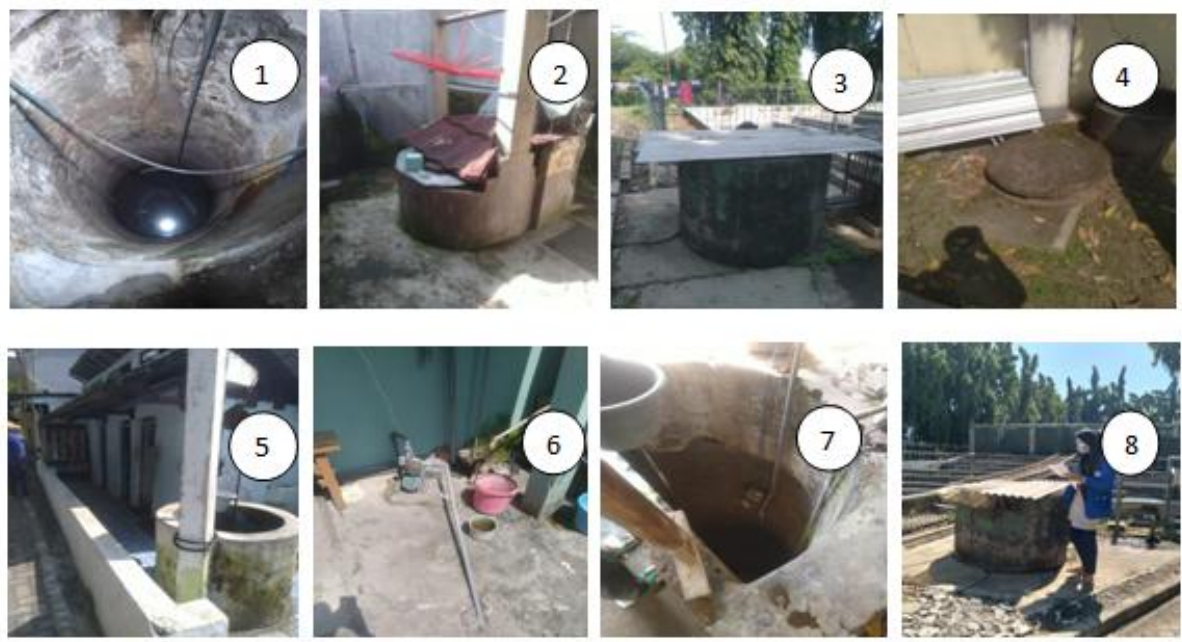

Fig. 8. The community well conditions

Noted: (1) Resident's well no.1. (2). Resident's well no.2. (3) Resident's well no. 3. (4). Resident's well no. 4. (5). Resident's well no.5. (6). Resident's well no. 6. (7). Resident's well no. 7 and (8) Resident's well no. 8 
Table 4. The chemical oxygen demand (COD) value test results in resident's well water [18]

\begin{tabular}{|c|c|c|c|c|c|c|}
\hline No & Sample & Parameter & Value & Condition of resident wells & Category distance from WWTP & WHO Standard \\
\hline 1 & Resident's Well 1 & COD & $12,2 \mathrm{mg} / \mathrm{L}$ & Moderate & Short Distance, 10 meter - 160 meter & $4,5 \mathrm{mg} / \mathrm{L}$ \\
\hline 2 & Resident's Well 2 & COD & $9,12 \mathrm{mg} / \mathrm{L}$ & Moderate & Short Distance, 10 meter - 160 meter & $4,5 \mathrm{mg} / \mathrm{L}$ \\
\hline 3 & Resident's Well 3 & COD & $3,05 \mathrm{mg} / \mathrm{L}$ & Moderate & Short Distance, 10 meter - 160 meter & $4,5 \mathrm{mg} / \mathrm{L}$ \\
\hline 4 & Resident's Well 4 & COD & $33,5 \mathrm{mg} / \mathrm{L}$ & Not qualify & Medium Distance, 161meter -200 meter & $4,5 \mathrm{mg} / \mathrm{L}$ \\
\hline 5 & Resident's Well 5 & COD & $3,05 \mathrm{mg} / \mathrm{L}$ & Moderate & Medium Distance, 161 meter -200 meter & $4,5 \mathrm{mg} / \mathrm{L}$ \\
\hline 6 & Resident's Well 6 & COD & $15,2 \mathrm{mg} / \mathrm{L}$ & Not Qualify & Medium Distance, 161meter -200 meter & $4,5 \mathrm{mg} / \mathrm{L}$ \\
\hline 7 & Resident's Well 7 & COD & $27,4 \mathrm{mg} / \mathrm{L}$ & Not Qualify & Long distance, 201 meter -270 meter & $4,5 \mathrm{mg} / \mathrm{L}$ \\
\hline 8 & Resident's Well 8 & COD & $3,05 \mathrm{mg} / \mathrm{L}$ & moderate & Long distance, 201 meter -270 meter & $4,5 \mathrm{mg} / \mathrm{L}$ \\
\hline
\end{tabular}

Simulation of decreasing COD in well with faily good

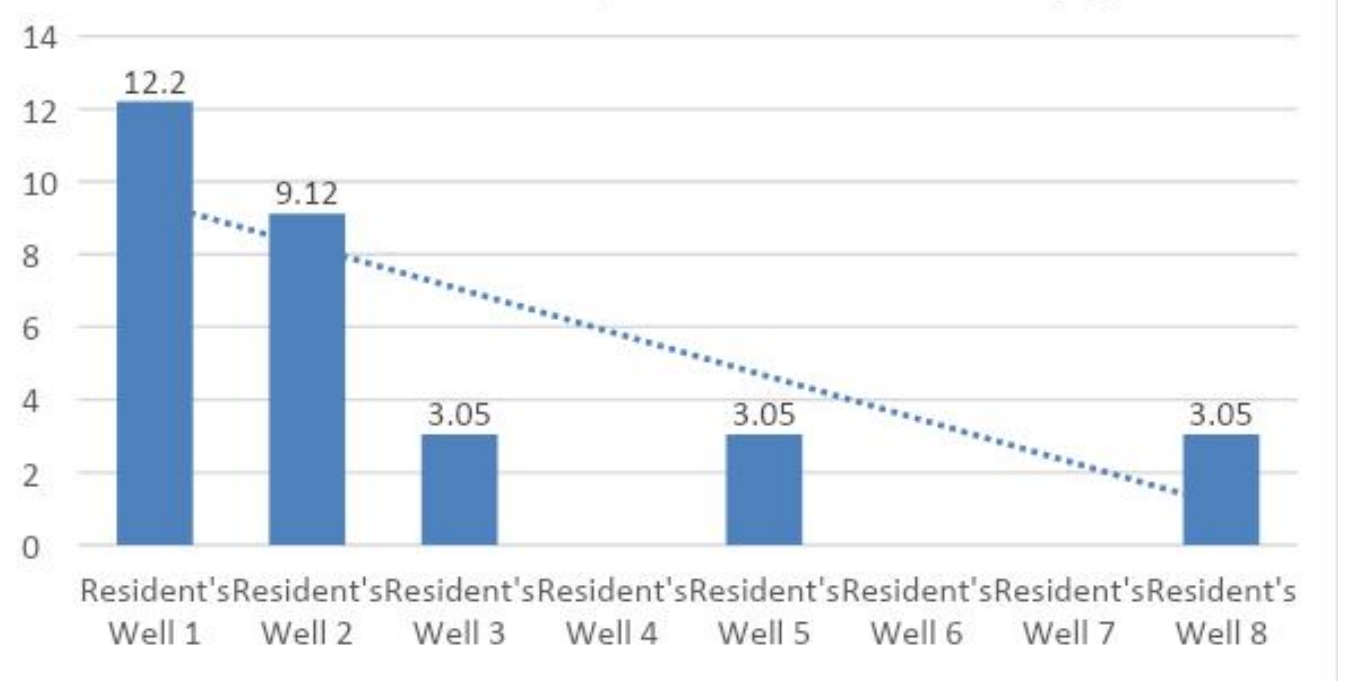

Fig. 9. Simulation of decreasing COD concentration in wells with fairly good conditions based on the distance from the tofu waste treatment plant 
decreasing chemical oxygen demand concentration in wells with fairly good conditions based on the distance from the tofu waste treatment plant.

Based on simulations and predictions, the farther the well is from the sewage treatment plant, the lower the concentration of chemical oxygen demand (cod) in the well water [19], based on the measurement of the water quality of residents' wells with fairly good/moderate well construction conditions. , by modeling $\mathrm{y}=$ 1.1866x + 10.63. Chemical oxygen demand (cod) concentrations in resident wells, 3, 5 and 8 showed COD concentrations below the quality standard (4 ppm), in the moderate category (good enough) $161 \mathrm{~m}-270 \mathrm{~m}$ from the distance from the sewage treatment plant. Fig. 1 shows that the farther from the tofu pulp processing plant, the brighter the color of the COD distribution, according to the modeling equation with a negative value of $y=-1.1866 x-10.63$, this indicates that the chemical oxygen demand (COD) concentration is getting smaller. The modeling does not involve the measurement results of well water for residents 4,6 and 7 because it has poor construction conditions and based on residents' information that the well has an unpleasant odor [20]

\section{CONCLUSIONS}

The effectiveness of the tofu industrial waste treatment installation is able to degrade waste for chemical oxygen demand (cod) value to reach $61.97 \mathrm{mg} / \mathrm{L}$, which is below the quality standard of $-275 \mathrm{mg} / \mathrm{L}$. The entry of domestic waste from community activities causes the waste processed by the WWTP to have a high chemical oxygen demand (cod) concentration load when it reaches the water body of the pirate river.

The chemical oxygen demand (cod) concentration in resident wells based on the category of distance from the tofu industrial waste processing installation shows that the farther the COD concentration is getting smaller, in some resident wells an unpleasant odor smells this occurs in wells that have poor construction, this is presumably due to the occurrence of waste flow instructions from WWTPs and instructions for domestic waste from community activities to residents' wells.

\section{DISCLAIMER}

All research materials used in this study are materials commonly used, nothing specific, there is no conflict of interest between the author and third parties and any parties for litigation. This research is intended for scientific advancement only, and this research was financed by the personal efforts of all authors.

\section{DATA AVAILABILITY}

All relevant data has been recorded with supporting file information. This research will help researchers to uncover critical areas related, especially in the study of the impact of tofu industrial waste treatment plants on value of chemical oxygen demand levels in the wells of the Villagers of Central Lamper, Semarang-Indonesia

\section{CONSENT}

The research was carried out in accordance with research standards that apply in the Republic of Indonesia, written consent has been collected and kept by the author.

\section{ACKNOWLEDGEMENTS}

The author would like to thank the head of the Lemper Tengah sub-district, Semarang Indonesia so that this research can be carried out properly.

\section{COMPETING INTERESTS}

Authors have declared that no competing interests exist.

\section{REFERENCES}

1. Palaniappan $\mathrm{M}$, et al. Clearing the waters: a focus on water quality solutions. ISBN: 978-92-807-3074-6 United Nations Environment Programme;2010.

2. S. Attia and H. A. E. Khalil. Urban metabolism and quality of life in informal areas. Real corp 2015. Plan together-right now-overall. from vision to reality for vibrant cities and regions. Proceedings of 20th International Conference on Urban Planning, Regional Development and Information Society, 2015, pp. 661674.

3. Kusdarini E, Suyadi S, Yanuwiyadi B, Hakim L. The supply of clean water and the problems in Benjeng sub-district, Gresik, Indonesia. In Proceedings of the 13th International Interdisciplinary Studies Seminar. 2019;1-7. 
4. Brindha K, Elango L. Impact of tanning industries on groundwater quality near a metropolitan city in India. Water Resour. Manag. 2012;26(6):1747-1761.

5. Kartamiharja MR, Sopandi W, Anggraeni D. Implementation of problem-based learning (PBL) approach in chemistry instructional with context of tofu liquid waste treatment. Int. J. Learn. Teach. Educ. Res. 2020;19(5):47-77.

6. Zangirolami-Raimundo $\mathrm{J}$, de $\mathrm{O} \mathrm{J}$. Echeimberg, Leone C. Research methodology topics: Cross-sectional studies. J. Hum. Growth Dev. 2018;28(3): 356-360.

7. Afiifah $\mathrm{AH}$. Pengujian chemical oxygen demand (cod) pada air limbah. Pusat Pengendalian Pembangunan Ekoregion Jawa (PPPEJ) Dengan Refluks Tertutup Secara Titrimetri. Iniversitas Islam Indonesia;2020.

Available:http://hdl.handle.net/123456789/ 29448

8. Vina N, Harling V, Tobi MD. Analysis of groundwater quality in dusun Salam and Randuacir, Argomulyo District. Journal of Physics: Conference Series. 2021;1783(1):12072.

9. Darkwah O, Scoville MD, Wang LK. Geographic information systems and remote sensing applications in environmental and water resources. Integr. Nat. Resour. Manag. 2021;197236.

10. Fathoni A. How to achieve improving the farmer share with model supply chain management for sme's tempe-tofu lamper tengah. J. Ekon. dan Bisnis Kontemporer. 2017;3(2).

11. Purnaweni $H$. Open Defecation Free (ODF) Program as an urgent public service in Semarang city, Central Java. E3S Web of Conferences. 2018;73:2010.

12. Widyasari IP. Peran serta masyarakat dalam pengelolaan limbah di kelurahan Jomblang kota Semarang. Program Pascasarjana Universitas Diponegoro ;2008.

13. Murtaza G, Habib R, Shan A, Sardar K, Rasool F, Javeed T. Municipal solid waste and its relation with groundwater contamination in Multan, Pakistan. Int. J. Appl. Res. 2017;3(4):434-441.

14. Carrard N, Foster T, Willetts J. Groundwater as a source of drinking water in southeast Asia and the Pacific. A multicountry review of current reliance and resource concerns. Water. 11, 2019;8:1605.

15. Hoekstra AY, Buurman J, Van Ginkel KCH. Urban water security: A review. Environ. Res. Lett. 2018;13(5):53002.

16. Katsanou K, Karapanagioti HK. Surface water and groundwater sources for drinking water. Applications of Advanced Oxidation Processes (AOPs) in Drinking Water Treatment, Springer. 2017;1-19.

17. Rahdriawan M, Pradoto W, Pratama FA, Hanifah MS, Muzdalifah S. Risks of community-based groundwater users in the transition to West Semarang drinking water supply. IOP Conference Series: Earth and Environmental Science. 2021;724(1);12081.

18. Mallik A, Arefin MA. Clean Water: Design of an efficient and feasible water treatment plant for rural South-Bengal. J Mech Eng Res Dev. 2018;41:156-167.

19. Singh S, Bhardwaj A, Verma VK. Remote sensing and GIS based analysis of temporal land use/land cover and water quality changes in Harike wetland ecosystem, Punjab, India. J. Environ. Manage. 2020;262;110355.

20. Hilili JM, Onuora DI, Hilili RU, Annah AF, Onmonya YA, Hilili $\mathrm{MH}$. Ground Water contamination: effects and remedies. Asian J. Environ. Ecol. 2021;39-58.

(c) 2021 Anugraheni and Isworo; This is an Open Access article distributed under the terms of the Creative Commons Attribution License (http://creativecommons.org/licenses/by/4.0), which permits unrestricted use, distribution, and reproduction in any medium, provided the original work is properly cited.

Peer-review history:

The peer review history for this paper can be accessed here: https://www.sdiarticle4.com/review-history/72591 